\title{
Lime and Soil Moisture Effects on Nitrous Oxide Emissions from a Urine Patch
}

\author{
Tim J. Clough,* Francis M. Kelliher, Robert R. Sherlock, and Colleen D. Ford
}

\begin{abstract}
Liming has been mooted as a mitigation option for lowering soil $\mathrm{N}_{2} \mathrm{O}$ emissions. This study investigated the effect of soil $\mathrm{pH}$ and soil water content on $\mathrm{N}_{2} \mathrm{O}$ and $\mathrm{N}_{2}$ emissions following the addition of synthetic urine $\left(500 \mathrm{~kg} \mathrm{~N} \mathrm{ha}^{-1}\right)$ containing ${ }^{15} \mathrm{~N}$-labeled urea-N. Soil pH treatments ranged from 4.7 to 7.2 with either saturated or field capacity soil. Dinitrogen and $\mathrm{N}_{2} \mathrm{O}$ fluxes were measured from soil cores kept on water tension tables for $85 \mathrm{~d}$ following urine- $\mathrm{N}$ addition. Soil inorganic $\mathbf{N}$ transformations were also monitored over time by destructively sampling soil cores on five occasions over the $85 \mathrm{~d}$. At field capacity, soil $\mathrm{pH}$ affected the $\mathrm{N}_{2} \mathrm{O}$ fluxes with the lowest cumulative $\mathrm{N}_{2} \mathrm{O}$ fluxes at soil $\mathrm{pH} \geq 5$.9. Nitrous oxide losses ranged from $<0.1$ to $0.4 \%$ of ${ }^{15} \mathrm{~N}$ applied in the field capacity treatment but this increased to be 0.4 to $1.7 \%$ of the ${ }^{15} \mathrm{~N}$ applied in the saturated treatment. Dinitrogen fluxes were low $\left(<23 \mathrm{ng} \mathrm{N}_{2}-\mathrm{N} \mathrm{cm}^{-2} \mathrm{~h}^{-1}\right)$ at field capacity but exceeded $4000 \mathrm{ng} \mathrm{N}_{2}-\mathrm{N} \mathrm{cm} \mathrm{cm}^{-2} \mathrm{~h}^{-1}$ under saturated conditions. Cumulative $\mathrm{N}_{2}$ fluxes increased with increasing soil $\mathrm{pH}$ in the saturated soil. The flux ratio of $\mathrm{N}_{2} \mathrm{O}-\mathrm{N} /\left(\mathrm{N}_{2} \mathrm{O}-\mathrm{N}+\mathrm{N}_{2}-\mathrm{N}\right)$ remained high $(0.68-0.71)$ under the field capacity treatment but decreased with time from 0.64 to 0.16 in the saturated treatment. This study suggests that while the use of soil liming has merit for lowering $\mathrm{N}_{2} \mathrm{O}$ emissions from urine patches where soils are at field capacity, the resulting $\mathrm{NO}_{3}-\mathrm{N}$ will be susceptible to enhanced rates of $\mathrm{N}_{2} \mathrm{O}$ and $\mathrm{N}_{2}$ loss if the soils are wetted up beyond field capacity.
\end{abstract}

$A^{\mathrm{T}}$ MOSPHERIC $\mathrm{N}_{2} \mathrm{O}$ concentrations have increased since pre-industrial times (Rockmann et al., 2003) with one of the main anthropogenic sources of $\mathrm{N}_{2} \mathrm{O}$ being agricultural soils (Perez et al., 2001). Nitrous oxide is globally important due to its role as a greenhouse gas and once oxidized to $\mathrm{NO}_{\mathrm{x}}$ it can catalyze stratospheric ozone destruction (Crutzen, 1981; Duxbury et al., 1993).

Some of the potential biological $\mathrm{N}_{2} \mathrm{O}$ production pathways in pasture soils include nitrification, denitrification, coupled nitrification-denitrification, and nitrifierdenitrification as defined by Wrage et al. (2001). Grazed pasture soils are a potential source of $\mathrm{N}_{2} \mathrm{O}$ due to elevated inorganic $\mathrm{N}$ pools, resulting from the high rates of urinary-N. Under suitable conditions $\mathrm{N}_{2} \mathrm{O}$ may be reduced in the soil to the environmentally benign $\mathrm{N}_{2}$, the ratio of $\mathrm{N}_{2} \mathrm{O}$ to $\mathrm{N}_{2}$ depending on factors such as soil $\mathrm{pH}$ (Firestone, 1982), soil moisture content, soil $\mathrm{NO}_{3}-\mathrm{N}$ concentration, C supply (Arah and Smith, 1990), the antecedent moisture regime (Dendooven et al., 1996), and temperature (Holtan-Hartwig et al., 2002).

Liming of pasture soils has also been shown to enhance nitrification rates (Sarathchandra and Upsdell, 1981). Since soil $\mathrm{pH}$ has a potential effect on $\mathrm{N}_{2} \mathrm{O}$ pro-

T.J. Clough, R.R. Sherlock, and C.D. Ford, Lincoln Univ., P.O. Box 84, Canterbury, New Zealand; F.M. Kelliher, Landcare Research, P.O. Box 69, Canterbury, New Zealand. Received 9 July 2003. *Corresponding author (clought@lincoln.ac.nz).

Published in Soil Sci. Soc. Am. J. 68:1600-1609 (2004).

(C) Soil Science Society of America

677 S. Segoe Rd., Madison, WI 53711 USA duction pathways, and the reduction of $\mathrm{N}_{2} \mathrm{O}$ to $\mathrm{N}_{2}$, it has been suggested that liming may provide an option for the mitigation of $\mathrm{N}_{2} \mathrm{O}$ from soils (Stevens et al. 1998; van der Weerden et al., 1999). A previous study demonstrated that liming could influence $\mathrm{N}_{2} \mathrm{O}$ fluxes derived from nitrification (Clough et al., 2003). Soil moisture levels, however, were inadequate for any potential denitrification to occur from the soil $\mathrm{NO}_{3}-\mathrm{N}$ pool that formed following nitrification. Nitrification and denitrification cannot be predicted solely from soil water content. However, studies have shown that as the soil moisture content increases to $\geq 60 \%$ water-filled pore space (WFPS) so to does the potential for $\mathrm{N}_{2} \mathrm{O}$ production via denitrification (Linn and Doran, 1984). To fully comprehend the potential effects of liming on $\mathrm{N}_{2} \mathrm{O}$ fluxes following urine- $\mathrm{N}$ deposition to soil, it is necessary to measure $\mathrm{N}_{2} \mathrm{O}$ fluxes at both low and high soil water contents since nitrification may be predominant at low soil moisture content and denitrification at high soil moisture content. Thus the objectives of this experiment were to assess the effects of soil liming on $\mathrm{N}_{2} \mathrm{O}$ and $\mathrm{N}_{2}$ fluxes following synthetic urine application to soil at different water contents.

\section{MATERIALS AND METHODS}

\section{Soil Characteristics}

A silt loam soil (Udic Ustochrept) was collected (0- to $10-\mathrm{cm}$ depth) from a sheep-grazed pasture. The native soil had a pH of 4.7 ( $10 \mathrm{~g}$ air dry soil: $25 \mathrm{~mL}$ water), a bulk density of $1 \mathrm{Mg} \mathrm{m}^{-3}$ and a loss-on-ignition of $8.6 \%$ (Blakemore et al., 1987). The air-dried soil was sieved $(<0.4 \mathrm{~cm})$, mixed with hydrated lime $\left[\mathrm{Ca}(\mathrm{OH})_{2}\right]$ at rates equal to $0,1.1,2.2,3.3,4.5$, and $5.6 \mathrm{~g} \mathrm{~kg}^{-1}$ and left for $2 \mathrm{wk}$, thus establishing soils with $\mathrm{pH}$ values 4.7, 5.3, 5.9, 6.6, 7.0, and 7.2, respectively. The limed soil was then packed into 'large' polyvinyl chloride (PVC) cores, (8.3-cm i.d. by $9.0 \mathrm{~cm}$ deep) or 'small' PVC cores, (5.0-cm i.d. by $9.0 \mathrm{~cm}$ deep) to a depth of $7.5 \mathrm{~cm}$ and a bulk density of $1.0 \mathrm{Mg} \mathrm{m}^{-3}$. Soil cores were then placed on water tension tables and wetted up with deionized water. These tension tables were constructed by placing a layer of nylon gauze in the bottom of a tray ( 36 by 40 by $4 \mathrm{~cm}$ ), followed by a 2-cm deep layer of washed sand and then applying a 2 -cm deep layer of silica flour $(75-\mu \mathrm{m}$ diam., air entry value of approximately $-20 \mathrm{kPa}$ ). The nylon gauze prevented sand movement down into the nylon tubing $(0.7-\mathrm{cm}$ i.d.) that was connected between the base of the tray and a water reservoir bottle that could be manipulated to adjust the water tension.

\section{Treatments}

Large cores were set up with two soil water treatments, 80 and $54 \%$ WFPS ( 0 or $-9.8 \mathrm{kPa}$ water potential, subsequently referred to as 'saturated' and 'field capacity', respectively) and the six soil $\mathrm{pH}$ treatments. There were three replicates giving

Abbreviations: WFPS, water-filled pore space; WSC, water-soluble carbon. 
36 large cores in total in a randomized complete-block design. Small cores had the same soil water treatments, but only five soil $\mathrm{pH}$ treatments $(4.7,5.3,5.9,6.6$, and 7.2$)$, replicated thrice and randomized in a complete-block design. The small core experiment was also replicated over time allowing for five destructive samplings on Days $8,19,36,51$, and 78 . Thus there were 150 small cores in total. All soil cores were placed on water tension tables for $4 \mathrm{wk}$ to allow soil moisture to equilibrate to the set water tensions. After this time a synthetic urine treatment was applied.

The $\mathrm{N}$ concentration in bovine urine depends on factors such as diet and water consumption but normally ranges from 8 to $15 \mathrm{~g} \mathrm{~N} \mathrm{~L}^{-1}$ (Whitehead, 1970). Nitrogen loadings in a urine patch can reach up to $1000 \mathrm{~kg} \mathrm{~N} \mathrm{ha}^{-1}$ (Haynes and Williams, 1993). Typically over $70 \%$ of the $\mathrm{N}$ in urine is present as urea (Bathurst, 1952; Doak, 1952). Thus a synthetic urine was applied, based on that used by Fraser et al. (1994), at a conservative rate equal to $5 \times 10^{-3} \mathrm{~g} \mathrm{~N} \mathrm{~cm}^{-2}\left(500 \mathrm{~kg} \mathrm{~N} \mathrm{ha}^{-1}\right)$ containing $9 \mathrm{~g} \mathrm{~N} \mathrm{~L}^{-1}$. The synthetic urine contained potassium bicarbonate, potassium chloride, potassium sulfate, glycine, and urea at rates of $23.33,8.35,2.29,4.84$, and $17.4 \mathrm{~g} \mathrm{~L}^{-1}$, respectively. This synthetic urine was carefully pipetted onto the soil surface. Urine applied to the large cores $(30 \mathrm{~mL})$ contained urea enriched at 24.8 atom $\%$ excess ${ }^{15} \mathrm{~N}$, relative to air, enabling the contribution of the urea to the $\mathrm{N}$-gas fluxes to be assessed. The urine applied to the small cores $(11 \mathrm{~mL})$ was not labeled. Soil cores, both large and small, remained on the tension tables until they were destructively analyzed at various times as described below. The experiment was maintained in a controlled temperature room at $23^{\circ} \mathrm{C}$ for $85 \mathrm{~d}$.

\section{Headspace Sampling and Gas Analysis}

Gas samples were taken from the headspace above the large cores on Days 2, 8, 12, 16, 19, 26, 30, 33, 40, 64, and 85. To facilitate headspace sampling the large cores were fitted with a gas-tight screw-on PVC lid containing a rubber septum to create a $0.081-\mathrm{L}$ headspace. After $3 \mathrm{~h}$, a gas sample was taken using a gas-tight syringe, fitted with a push button valve (SGE Inc., Austin, TX), and transferred into a pre-evacuated $(<100 \mathrm{kPa})$ 12-mL vial (Exetainer tubes, Labco Ltd, UK). Samples were analyzed for $\mathrm{N}_{2} \mathrm{O}$ concentration utilizing gas chromatography as described by Sherlock et al. (2002). In brief this consisted of a Varian (Walnut Creek, CA) Aerograph Series 2800 equipped with a ${ }^{63} \mathrm{Ni}$ electron capture detector (Pye-Unicam, Cambridge, UK) and a stainless steel column (4-m length, 3-mm i.d.) packed with Porapak Q (80/100 mesh) (Alltech Associates, Deerfield, IL). Detector and column temperatures were 350 and $20^{\circ} \mathrm{C}$, respectively. On Days 2, 12, $19,26,40$, and 64 determinations were also made of the ${ }^{15} \mathrm{~N}$ enrichment of the $\mathrm{N}_{2} \mathrm{O}$ and $\mathrm{N}_{2}$ gases in the headspace, using an isotope ratio mass spectrometer (PDZ Europa, Crewe, UK) and the methods of Stevens et al. (1993). The ${ }^{15} \mathrm{~N}$ enrichment and fluxes of ${ }^{15} \mathrm{~N}$-labeled gases were calculated using the equations of Mulvaney and Boast (1986). It was assumed that any native $\mathrm{NO}_{3}-\mathrm{N}$ in the soil would be insignificant compared with the $\mathrm{NO}_{3}-\mathrm{N}$ pool formed following urine application, and that the $\mathrm{NO}_{3}-\mathrm{N}$ pool formed from the urine would be uniformly labeled with ${ }^{15} \mathrm{~N}$.

\section{Soil Measurements}

Nondestructive soil surface $\mathrm{pH}$ measurements were periodically taken throughout the experiment, using a calibrated flat surface $\mathrm{pH}$ electrode (Broadley-James Corp., Irvine, CA.). Destructive sampling of the small soil cores was performed on Days 8, 19,36, 51, and 78, to determine the changes in soil inorganic $\mathrm{N}$ concentrations with time, following the urine- $\mathrm{N}$ application. Immediately before destructive sampling the small cores, still enclosed in the PVC casing, were placed in a 0.6-L Mason jar that was then sealed with a Perfit seal (Unilever, NZ) fitted with a septum. After $1 \mathrm{~h}$, a headspace gas sample was taken for $\mathrm{N}_{2} \mathrm{O}$, as described above. The purpose of this was to determine if the $\mathrm{N}_{2} \mathrm{O}$ gas fluxes from the small cores could be reconciled with the soil inorganic $\mathrm{N}$ concentrations, soil $\mathrm{pH}$, or soil water content measurements determined immediately after the gas sampling. After taking the gas sample, the small soil core was removed from the Mason jar and carefully separated into three depths, 0 to $2.5,2.5$ to 5.0 , and 5.0 to $7.5 \mathrm{~cm}$. During this process the soil surface $\mathrm{pH}$ was measured in situ at 0-, 2.5-, and 5-cm depths using the flat surface $\mathrm{pH}$ electrode. A gravimetric water determination was performed on a soil subsample from each depth. Soils from each depth were then bulked and a subsample extracted to attain the average inorganic $\mathrm{N}$ concentration over the whole soil core. Soil inorganic N concentrations of both large and small cores were determined by extracting the soil with $2 M$ $\mathrm{KCl}$ (Mulvaney, 1996) and analyzing the extracts with colorimetric flow injection methods for $\mathrm{NH}_{4}-\mathrm{N}, \mathrm{NO}_{2}-\mathrm{N}$, and $\mathrm{NO}_{3}-\mathrm{N}$ (Tecator and Alpkem FS3000). Extracts were stored for a maximum of $48 \mathrm{~h}$ at $4^{\circ} \mathrm{C}$ before analysis. Net nitrification rates in the small soil cores were determined by calculating the change in soil inorganic $\mathrm{N}$ concentrations divided by the number of days between soil sampling.

The large soil cores were destructively sampled on Day 85 just after a gas headspace sample had been taken. Soil surface $\mathrm{pH}$ measurements were followed by removal of the soil from the $0-$ to $2.5-\mathrm{cm}$ depth. Soil from this depth, and each depth that followed were subsampled for gravimetric soil water and water-soluble C (WSC) determinations (Burford and Bremner, 1975). Total, organic, and inorganic WSC were determined using a TOC-5000A carbon analyzer (Shimadzu, Australia). The headspace cover was then placed on the soil core again and a headspace gas sample was taken to determine the flux from the remaining $2.5-$ to $7.5-\mathrm{cm}$ soil depth. The soil from the 2.5 - to $5.0-\mathrm{cm}$ depth was then removed and subsampled, as for the $0-$ to $2.5-\mathrm{cm}$ depth. The process was repeated for the final 5.0- to $7.5-\mathrm{cm}$ depth. Soil from each depth was then bulked and analyzed for inorganic $\mathrm{N}$, as for the small cores. Subsamples of the silica flour directly underneath the large cores were also analyzed for inorganic $\mathrm{N}$. The ${ }^{15} \mathrm{~N}$ enrichments of the inorganic $\mathrm{N}$ in the large soil cores were determined according to Stevens and Laughlin (1994) and Laughlin et al. (1997). Nitrogen-15 determinations of total soil $\mathrm{N}$ were made on air-dried subsamples of large core bulk soils with an elemental analyzer linked to an isotope ratio mass spectrometer (PDZ-Europa). Soil organic $\mathrm{N}$ was determined as the difference between total- $\mathrm{N}$ minus the inorganic $\mathrm{N}$.

Total $\mathrm{N}_{2} \mathrm{O}-\mathrm{N}$ and $\mathrm{N}_{2}$ losses were calculated by integrating the measured gas fluxes over time. Statistical analyses were performed using Minitab11 (Minitab Inc., State College, PA). Data from individual days were analyzed using a two-way ANOVA with soil $\mathrm{pH}$ and water treatments as factors. Regression analyses were performed to assess the relationship between the soil $\mathrm{pH}$ treatment and measured variables.

\section{RESULTS}

Nitrous oxide fluxes from the large cores increased following urine application (Fig. 1). On any particular day of observation these $\mathrm{N}_{2} \mathrm{O}$ fluxes, when averaged over both water treatments, did not differ significantly with soil $\mathrm{pH}$ treatment. However, when the $\mathrm{N}_{2} \mathrm{O}$ data 


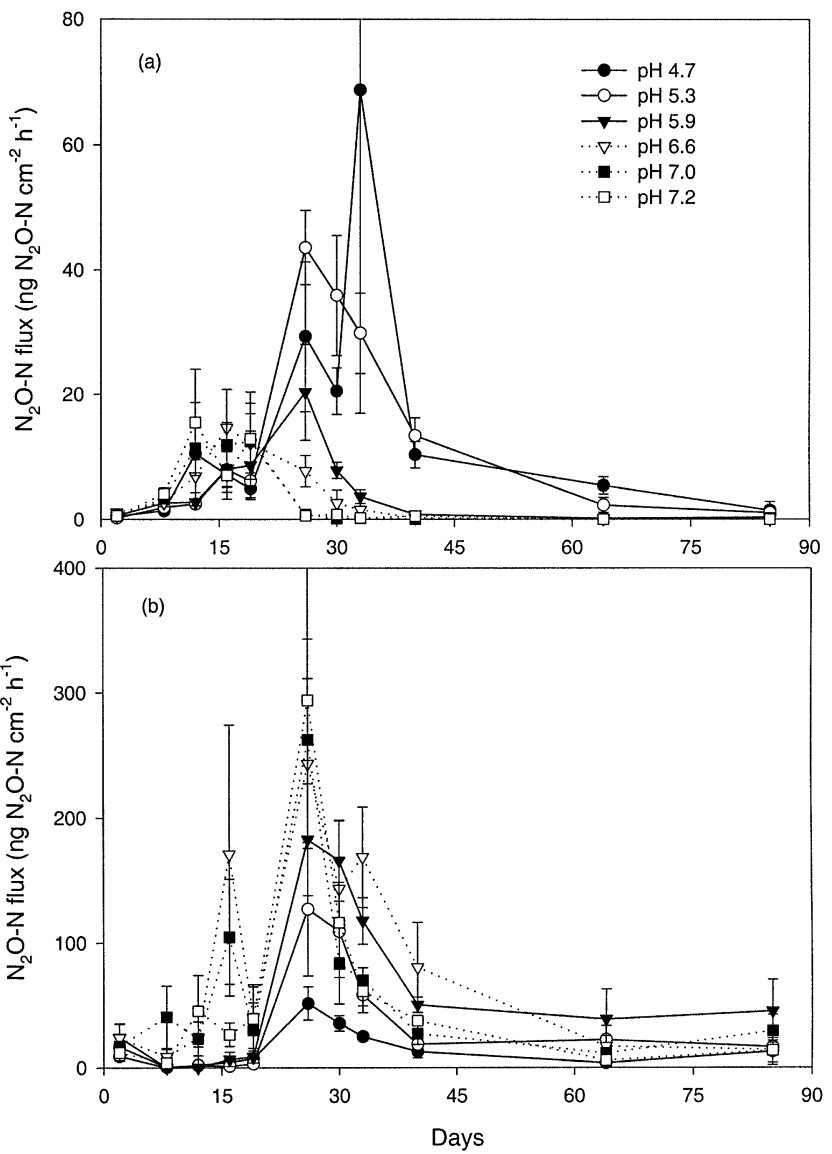

Fig. 1. Effect of initial soil $\mathrm{pH}$ on $\mathrm{N}_{2} \mathrm{O}-\mathrm{N}$ fluxes from the large soil cores over time under (a) field capacity and (b) saturated soil water conditions. Error bars represent the standard error of the mean. $(N=3)$.

were analyzed within a particular water treatment, that is, a one-way ANOVA with soil $\mathrm{pH}$ as a factor, then significant differences $(P<0.01)$ occurred due to the soil $\mathrm{pH}$ treatments, especially between Days 26 and 64 for the field capacity treatment (Fig. 1a). In the field capacity treatment the soils with $\mathrm{pH} \geq 5.9$ produced the least $\mathrm{N}_{2} \mathrm{O}$. In the saturated treatment (Fig. 1b), the lowest fluxes occurred at the lowest soil $\mathrm{pH}, 4.7$. The soil water treatment significantly affected the magnitude of the $\mathrm{N}_{2} \mathrm{O}$ fluxes $(P<0.001)$ when averaged across all soil pH treatments on Days 2, 16, 30, 33, 40, 64, and 85. On these occasions the $\mathrm{N}_{2} \mathrm{O}$ fluxes were higher under the saturated soil treatment. Interactions between the soil $\mathrm{pH}$ and soil water treatments occurred on Day 33 $(P<0.001)$ and Day $40(P<0.01)$. On these days the highest $\mathrm{N}_{2} \mathrm{O}$ fluxes in the field capacity treatment occurred at low soil $\mathrm{pH}$ and the highest $\mathrm{N}_{2} \mathrm{O}$ fluxes in the saturated soils occurred at higher values of soil $\mathrm{pH}$ (Fig. 1). The maximum flux of $294 \mathrm{ng} \mathrm{N} \mathrm{N}_{2} \mathrm{O}-\mathrm{N} \mathrm{cm}{ }^{-2} \mathrm{~h}^{-1}$ occurred under saturated soil conditions (Fig. 1b).

Upon destruction of the large soil cores the flux of $\mathrm{N}_{2} \mathrm{O}$ did not differ with depth in the field capacity treatment, but did in the saturated treatment $(P<0.01)$. In the saturated treatment the $\mathrm{N}_{2} \mathrm{O}$ fluxes evolving from the $0-, 2.5-$, and 5-cm deep surfaces averaged 12, 42, and $19 \mathrm{ng} \mathrm{N}_{2} \mathrm{O}-\mathrm{N} \mathrm{cm} \mathrm{cm}^{-2} \mathrm{~h}^{-1}$, respectively. These fluxes had poor correlations with soil $\mathrm{pH}$ or WSC $(r \leq 0.4)$.
Atom $\%$ of ${ }^{15} \mathrm{~N}$ enrichment of the $\mathrm{N}_{2} \mathrm{O}$ flux varied with soil $\mathrm{pH}$ and water treatments (Table 1). On Day 2 the ${ }^{15} \mathrm{~N}$ enrichment was greatest at the highest soil $\mathrm{pH}$ while on Days 26 to 64 this was reversed with the lowest ${ }^{15} \mathrm{~N}$ enrichments occurring at the highest soil $\mathrm{pH}$. Soil water treatment affected the ${ }^{15} \mathrm{~N}$ enrichment of the $\mathrm{N}_{2} \mathrm{O}$ flux on Days 2, 12, and 64 (Table 1) with higher enrichments in the field capacity treatment on Days 2 and 12, but higher enrichments in the saturated treatment on Day 64. The only interaction between soil $\mathrm{pH}$ and water treatment was on Day 64 when the highest enrichments occurred in the saturated soils at the higher soil $\mathrm{pH}$ values $(\geq 6.6)$.

Cumulative $\mathrm{N}_{2} \mathrm{O}-\mathrm{N}$ emissions from the large soil cores (Fig. 2a) were affected by an interaction between soil $\mathrm{pH}$ and soil water treatments $(P<0.01)$. Under saturated soil conditions the cumulative $\mathrm{N}_{2} \mathrm{O}-\mathrm{N}$ emissions were higher and increased with soil $\mathrm{pH}$ between $\mathrm{pH} 4.7$ to 6.6. In the field capacity treatment, the cumulative $\mathrm{N}_{2} \mathrm{O}-\mathrm{N}$ emissions were lower and decreased with increasing soil pH (Fig. 2a). The total loss as $\mathrm{N}_{2} \mathrm{O}-\mathrm{N}$ ranged from 0.06 to $0.40 \%$ of the urea $-{ }^{15} \mathrm{~N}$ applied at field capacity and from 0.41 to $1.66 \%$ under saturated conditions.

Fluxes of $\mathrm{N}_{2}$ were too low to be detected on Days 2 and 85 . In the field capacity treatment the $\mathrm{N}_{2}$ flux, averaged over all $\mathrm{pH}$ treatments, was $<23 \mathrm{ng} \mathrm{N}_{2}-\mathrm{N} \mathrm{cm}^{-2} \mathrm{~h}^{-1}$ on Days 12 and 19 and then decreased to be $<5 \mathrm{ng} \mathrm{N}_{2}-\mathrm{N}$ $\mathrm{cm}^{-2} \mathrm{~h}^{-1}$ thereafter. Significantly higher $\mathrm{N}_{2}$ fluxes occurred under saturated soil conditions peaking on Day 26 with the lowest $\mathrm{N}_{2}$ flux from the soil at pH 4.7 (Fig. 3). A significant linear regression $\left(P<0.05, r^{2}=0.26\right)$ showed cumulative $\mathrm{N}_{2}$ fluxes, in the saturated treatment, increased with increasing soil pH (Fig. 2b). The mean enrichments of the nitrate pool from which the labeled $\mathrm{N}_{2}$ was derived, ${ }^{15} X_{\mathrm{N}}$ as defined by Mulvaney and Boast (1986), were $0.17,0.24,0.18,0.20$, and 0.24 for Days $12,19,26,40$, and 64 , respectively, with no significant differences due to soil $\mathrm{pH}$. Cumulative $\mathrm{N}_{2}$ flux between Days 2 and 64 averaged 1136 and $10 \mu \mathrm{g} \mathrm{N}_{2}-\mathrm{N} \mathrm{cm}^{-2}$ in the saturated and field capacity treatments, respectively. This equated to $22.3 \%$ (std. dev. 19.0) and $0.4 \%$ (std. dev. 0.6) of the urea- ${ }^{15} \mathrm{~N}$ applied, respectively.

Soil water treatment affected the flux ratio of $\mathrm{N}_{2} \mathrm{O}$ $\mathrm{N} /\left(\mathrm{N}_{2} \mathrm{O}-\mathrm{N}+\mathrm{N}_{2}-\mathrm{N}\right)$ evolved with a significantly higher ratio in the field capacity treatment than in the saturated treatment on Days 19, 26, 40, and 64 (Table 2) but with no effect due to soil $\mathrm{pH}$ on any sampling occasion. In the saturated treatment, the ratio varied with sampling time $(P<0.01)$ being higher on Days 12 and 26 than on Days 19, 40, and 64 .

Data from destructive sampling of the small cores showed that soil $\mathrm{pH}$, when averaged across both soil water treatments, consistently affected soil $\mathrm{NH}_{4}-\mathrm{N}$ concentrations $(P<0.01)$. Soil $\mathrm{NH}_{4}-\mathrm{N}$ concentrations were lowest at the highest values of soil pH (Fig. 4a). Soil $\mathrm{NH}_{4}-\mathrm{N}$ concentrations, when averaged across all soil pH treatments, did not differ due to soil water treatments (Fig. 5a).

Soil concentrations of $\mathrm{NO}_{2}-\mathrm{N}$ averaged across both water treatments were influenced by the soil $\mathrm{pH}$ treat- 
Table 1. Enrichment of ${ }^{15} \mathrm{~N}($ atom $\%)$ in the $\mathrm{N}_{2} \mathrm{O}$ flux from soils as affected by the initial soil pH and the soil water treatment (FC = field capacity, SAT = saturated) over time.

\begin{tabular}{|c|c|c|c|c|c|c|}
\hline & \multicolumn{6}{|c|}{ Time, d } \\
\hline & 2 & 12 & 19 & 26 & 40 & 64 \\
\hline \multicolumn{7}{|l|}{ Soil pH } \\
\hline 4.7 & 1.1 & 15.9 & 19.2 & 19.5 & 18.1 & 16.3 \\
\hline 5.3 & 1.4 & 16.2 & 19.4 & 18.4 & 17.5 & 14.1 \\
\hline 5.9 & 1.5 & 12.8 & 19.4 & 17.1 & 14.1 & 9.6 \\
\hline 6.6 & 2.1 & 15.7 & 17.6 & 16.0 & 13.2 & 9.3 \\
\hline 7.0 & 3.4 & 17.4 & 18.0 & 13.9 & 13.8 & 8.1 \\
\hline \multirow[t]{2}{*}{7.2} & 4.8 & 14.8 & 17.5 & 12.3 & 13.8 & 11.1 \\
\hline & $*$ & NS & NS & $* *$ & $* *$ & $*$ \\
\hline $\begin{array}{l}\text { LSD }(0.01) \dagger \\
\text { df }=30, n=6\end{array}$ & 3.1 & 3.0 & 1.2 & 1.7 & 1.6 & 3.1 \\
\hline \multicolumn{7}{|l|}{ Soil water } \\
\hline FC & 3.2 & 17.7 & 18.2 & 16.2 & 14.9 & 8.4 \\
\hline \multirow[t]{2}{*}{ SAT } & 1.6 & 13.2 & 18.8 & 16.3 & 15.3 & 13.9 \\
\hline & $*$ & $* *$ & NS & NS & NS & $* *$ \\
\hline $\begin{array}{l}\text { LSD }(0.01) \\
\text { df }=34, n=18\end{array}$ & 1.9 & 0.9 & 0.4 & 0.8 & 0.7 & $\mathbf{1 . 0}$ \\
\hline \multicolumn{7}{|c|}{ Soil $\mathbf{p H} \times$ soil water interaction } \\
\hline & NS & NS & NS & NS & NS & $* *$ \\
\hline $\begin{array}{l}\text { LSD (0.01) } \\
\text { df }=\mathbf{2 4 ,} n=3\end{array}$ & 3.7 & 5.5 & 2.5 & 3.4 & 2.9 & 2.5 \\
\hline
\end{tabular}

$* \boldsymbol{P}<0.05$.

** $\boldsymbol{P}<0.01$

$\dagger$ The least significant difference (LSD) between treatment means is shown for a $1 \%$ level of significance, $P$ values $>0.05=$ nonsignificant $(\mathrm{NS})$.

ment on Days 8,36 , and $51(P<0.05)$. Concentrations increased with increasing soil $\mathrm{pH}$ (Fig. 4b). Soil $\mathrm{NO}_{2}-\mathrm{N}$ concentrations were also affected by soil water treatments and were higher $(P<0.05)$ in the saturated treatment on Days 36 and 51 (Fig. 5b).

Soil $\mathrm{pH}$ treatments caused the soil $\mathrm{NO}_{3}-\mathrm{N}$ concentrations, averaged across both water treatments, to be elevated at the highest values of soil $\mathrm{pH}(P<0.01)$ on Days 8 and 19. The maximum $\mathrm{NO}_{3}-\mathrm{N}$ concentration (1059 $\mu \mathrm{g} \mathrm{g}^{-1}$ dry soil) occurred at soil $\mathrm{pH} 7.2$ on Day 19 (Fig. 4c). The saturated soil treatment resulted in lower $\mathrm{NO}_{3}-\mathrm{N}$ concentrations $(P<0.01)$ from Day 19 onwards (Fig. 5c). No interaction occurred between treatments to affect soil $\mathrm{NO}_{3}-\mathrm{N}$ concentrations.

Soil $\mathrm{NH}_{4}-\mathrm{N}$ concentrations in the large soil cores on Day 85 were lowest at the highest soil pH $(P<0.01)$ and were unaffected by water treatment (Fig. 4a, 5a). The soil $\mathrm{NO}_{2}-\mathrm{N}$ concentrations in the large cores on Day 85 were at a maximum at $\mathrm{pH} 7.2(P<0.01)$ and in the saturated treatment $(P<0.05)$ (Fig. $4 \mathrm{~b}, 5 \mathrm{~b})$. Soil $\mathrm{NO}_{3}-\mathrm{N}$ concentrations in the large cores on Day 85 were unaffected by soil $\mathrm{pH}$ treatment (Fig. 4c) but were greater $(P<0.01)$ at field capacity (Fig. $5 \mathrm{c})$.

On Day 85, the mean enrichments over all treatments for soil $\mathrm{NH}_{4}-\mathrm{N}, \mathrm{NO}_{2}-\mathrm{N}$, and $\mathrm{NO}_{3}-\mathrm{N}$ were 2.17, 0.60, and 10.17 atom $\%{ }^{15} \mathrm{~N}$, respectively. The enrichment of $\mathrm{NH}_{4}-\mathrm{N}$ decreased with increasing soil $\mathrm{pH}$ from 3.0 to 0.4 atom $\%{ }^{15} \mathrm{~N}(P<0.05)$ but was unaffected by soil water treatment. The ${ }^{15} \mathrm{~N}$ enrichment of $\mathrm{NO}_{2}-\mathrm{N}$ was not affected by soil treatments. The enrichment of the $\mathrm{NO}_{3}-\mathrm{N}$ was 11.5 atom $\%{ }^{15} \mathrm{~N}$ in the saturated treatment but 8.9 atom $\%{ }^{15} \mathrm{~N}$ in the field capacity treatment $(P<$ $0.05)$ and was unaffected by soil $\mathrm{pH}$ treatment. Recovery of ${ }^{15} \mathrm{~N}$ applied as urea in the organic fraction averaged $30.6 \%$ (12.7 std. dev.) and 7.5\% (13.7 std. dev.) differing
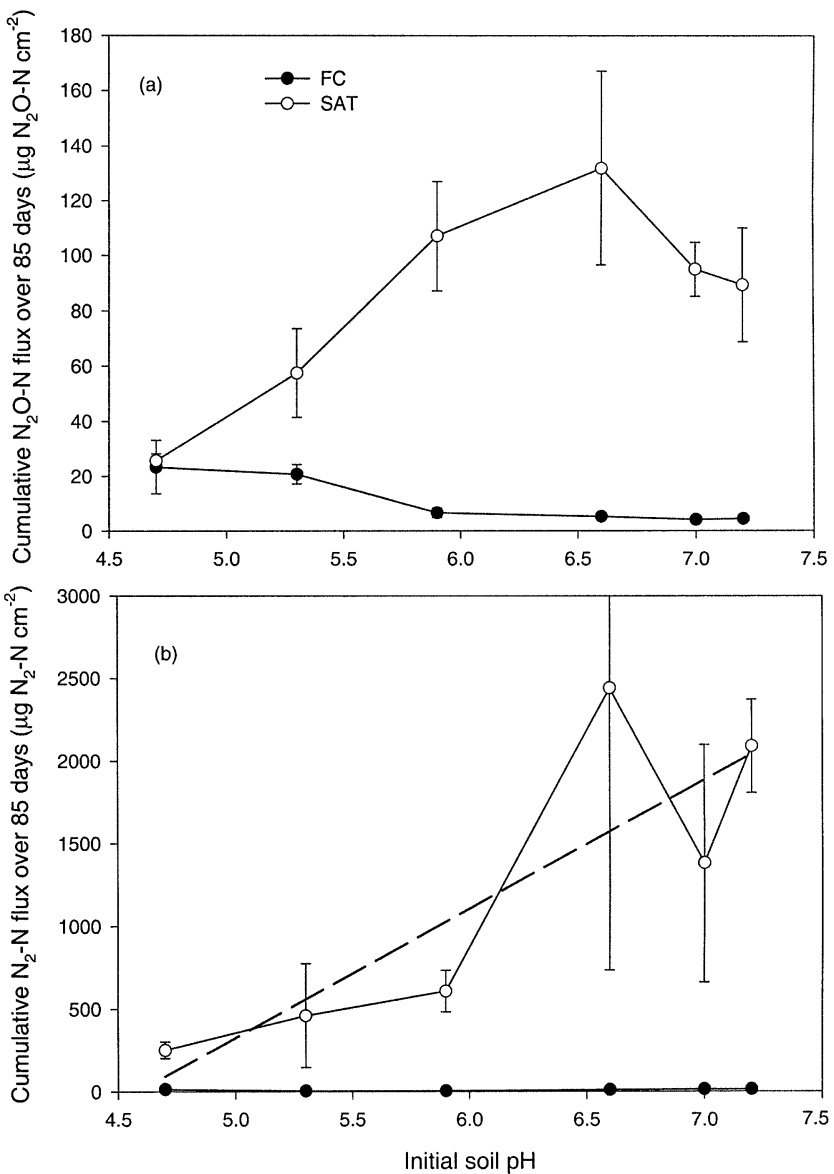

Fig. 2. Cumulative (a) $\mathrm{N}_{2} \mathrm{O}-\mathrm{N}$ flux and (b) $\mathrm{N}_{2}-\mathrm{N}$ flux from the large soil cores after $85 \mathrm{~d}$ versus the initial soil $\mathrm{pH} . \mathrm{FC}=$ field capacity, SAT $=$ saturated. Error bars represent the standard error of the mean. $(N=3)$. The dotted line represents linear regression of soil $\mathrm{pH}$ and cumulative $\mathrm{N}_{2}$ flux $\left(P<0.05, r^{2}=0.26\right)$. 


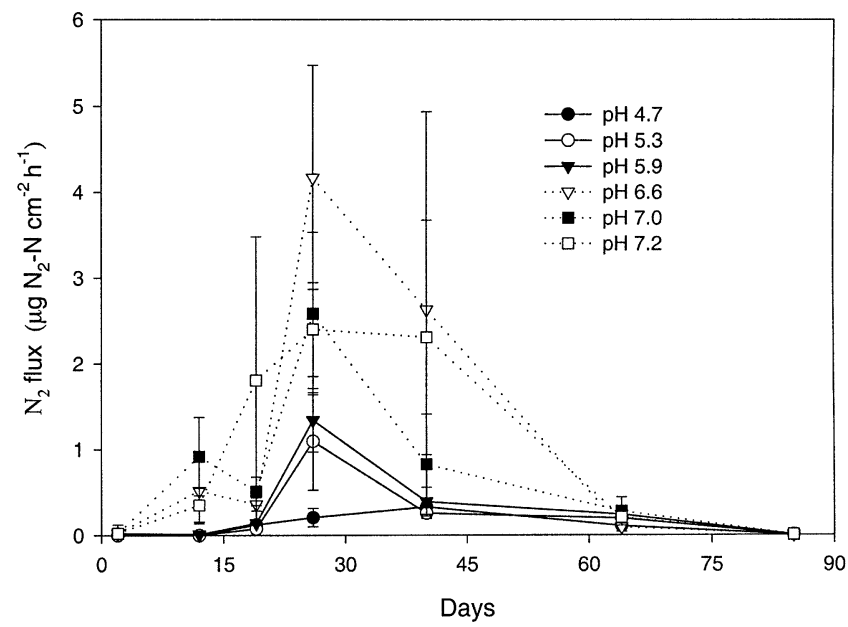

Fig. 3. Effect of initial soil $\mathbf{p H}$ on $\mathbf{N}_{2}-\mathbf{N}$ fluxes from large soil cores over time under saturated soil water conditions. Error bars represent the standard error of the mean. $(N=3)$.

between field capacity and saturated treatments, respectively $(P<0.01)$. Total recovery of the ${ }^{15} \mathrm{~N}$ applied, from the $\mathrm{N}$ pools measured, averaged $48 \%$ across all soil cores $(15$ std. dev.). There were no significant treatment differences in total $\mathrm{N}$ recovery due to the large variability in the data, despite the large $\mathrm{N}_{2}$ losses in the saturated treatment.

Inorganic $\mathrm{N}$ levels were also elevated in the silica flour directly under the soil cores. Mean $\mathrm{NH}_{4}-\mathrm{N}, \mathrm{NO}_{2}-\mathrm{N}$, and $\mathrm{NO}_{3}-\mathrm{N}$ concentrations in the saturated treatment were 3.6, 0.4, and $7.4 \mu \mathrm{g} \mathrm{N} \mathrm{g}^{-1}$ silica flour, respectively, while in the field capacity treatment the respective mean concentrations were $0.6,0.1$, and $35.4 \mu \mathrm{g} \mathrm{N} \mathrm{g}^{-1}$ silica flour.

Net nitrification rates were influenced by soil $\mathrm{pH}$ (Table 3) with greater rates of $\mathrm{NH}_{4}-\mathrm{N}$ decline particularly between Days 8 to 19 at elevated soil $\mathrm{pH}$ levels. Soil $\mathrm{NH}_{4}-\mathrm{N}$ concentrations didn't begin to decline in the $\mathrm{pH} 4.7$ to 5.3 treatments until after Day 19. The rates at which soil $\mathrm{NO}_{3}-\mathrm{N}$ increased were also greater at the higher levels of soil $\mathrm{pH}$ (Table 3 ) between Days 0 and 19. Between Days 8 and $19, \mathrm{NO}_{3}-\mathrm{N}$ increased at a higher rate in the field capacity treatment compared with the saturated treatment, 80 and $41 \mu \mathrm{g} \mathrm{NO}{ }_{3}-\mathrm{N} \mathrm{g}^{-1}$ dry soil $\mathrm{d}^{-1}$, respectively.

On Days 8, 19, 36, and 51 the mean water-filled pore space (WFPS) in the small cores, averaged over the entire depth of the soil core (standard deviations in brackets), were 75(3), 70(7), 76(4), and 64(7)\%, respec-

Table 2. The flux ratio of $\mathrm{N}_{2} \mathrm{O}-\mathrm{N} /\left(\mathrm{N}_{2} \mathrm{O}-\mathrm{N}+\mathrm{N}_{2}-\mathrm{N}\right)$ from large soil cores over time at two water treatments $(\mathrm{FC}=$ field capacity, SAT = saturated).

\begin{tabular}{lccccc}
\hline & \multicolumn{5}{c}{ Time, d } \\
\cline { 2 - 6 } Water treatment & $\mathbf{1 2}$ & 19 & $\mathbf{2 6}$ & 40 & $\mathbf{6 4}$ \\
\hline FC & $\mathbf{0 . 7 1}$ & $\mathbf{0 . 7 1}$ & $\mathbf{0 . 9 8}$ & $\mathbf{0 . 9 7}$ & $\mathbf{0 . 6 8}$ \\
SAT & $\mathbf{0 . 6 4}$ & $\mathbf{0 . 1 1}$ & $\mathbf{0 . 4 9}$ & $\mathbf{0 . 1 3}$ & $\mathbf{0 . 1 6}$ \\
& NS & $* *$ & $* *$ & $* *$ & $* *$
\end{tabular}

LSD $(0.01) \dagger$

$\begin{array}{llllll}\text { df }=34, n=18 & 0.09 & 0.05 & 0.07 & 0.02 & 0.07\end{array}$

$* \boldsymbol{P}<0.05$.

*** $\boldsymbol{P}<\mathbf{0 . 0 1}$

$\dagger$ The least significant difference (LSD) between treatment means and is calculated for a $1 \%$ level of significance. $P$ values $>0.05=$ nonsignificant (NS).
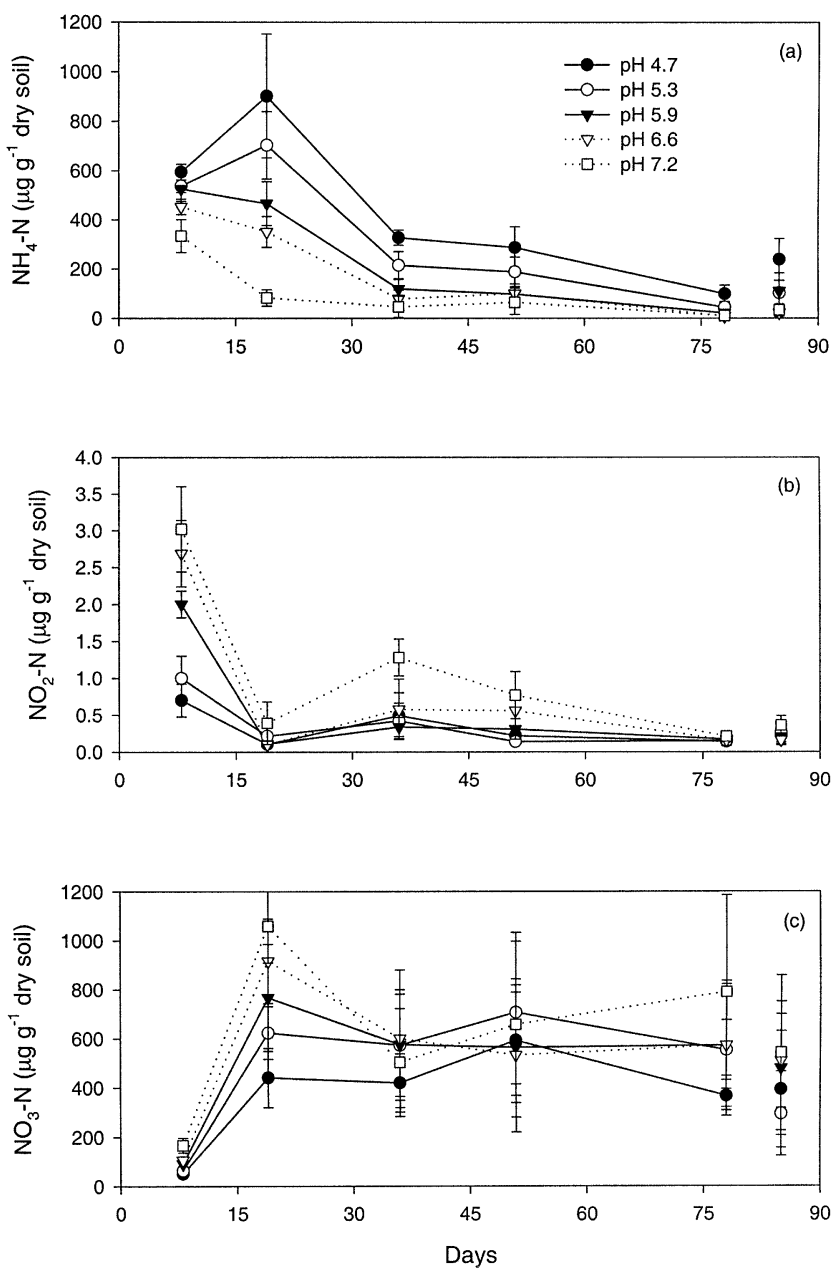

Fig. 4. Effect of initial soil $\mathrm{pH}$ on the changes in inorganic $\mathrm{N}$ in the small soil cores over time and the inorganic $\mathbf{N}$ remaining in the large soil cores on Day 85. Data are the average of both water treatments. (a) $\mathrm{NH}_{4}-\mathrm{N}$, (b) $\mathrm{NO}_{2}-\mathrm{N}$, and (c) $\mathrm{NO}_{3}-\mathrm{N}$ soil concentrations are shown. Error bars represent the standard error of the mean. $(N=6)$.

tively, in the saturated treatment. The respective mean values in the field capacity treatment were 57(4), 49(3), $32(5)$, and 33(3)\%. The WFPS in the large cores at destruction averaged $84(3) \%$ at saturation and $46(8) \%$ at field capacity. Water-filled pore space had a dominant effect on the $\mathrm{N}_{2} \mathrm{O}$ fluxes with higher fluxes above approximately $60 \%$ WFPS (Fig. 6). In the saturated soil treatment both large and small soil cores were of similar WFPS and conditions were suitable for denitrification. In the field capacity treatment, the small soil cores were drier and WFPS was more variable than intended at the end of the experiment, due to high evaporation and the tension table not being monitored at a high enough frequency. However the soil moisture in these small cores was still at a level suitable for nitrification of $\mathrm{NH}_{4}-\mathrm{N}$ as shown by its conversion to $\mathrm{NO}_{3}-\mathrm{N}$.

The initial differences in the soil surface $\mathrm{pH}$ resulting from liming were nullified following urine application with soil $\mathrm{pH}$ increasing to a mean, averaged across all treatments, of 8.88 . The surface soil $\mathrm{pH}$ was unaffected by soil water treatment. After Day 36, the soil $\mathrm{pH}$ treatment, averaged across soil water treatments, once again imposed a significant effect on the soil surface $\mathrm{pH}$ in 

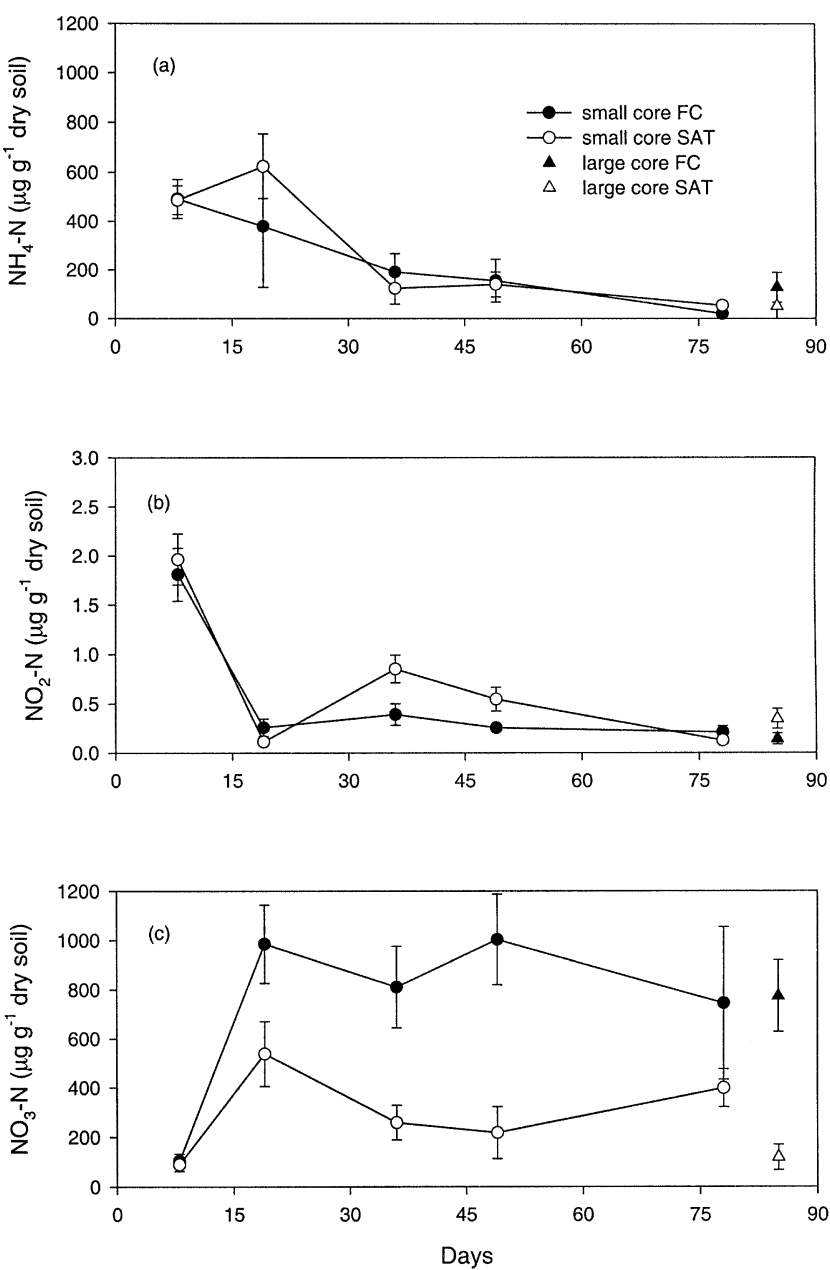

Fig. 5. Effect of soil water treatment on inorganic $\mathbf{N}$ in the small soil cores over time and the inorganic $\mathbf{N}$ remaining in the large soil cores on Day 85. Data are the average of all soil $\mathrm{pH}$ treatments. (a) $\mathrm{NH}_{4}-\mathrm{N}$, (b) $\mathrm{NO}_{2}-\mathrm{N}$, and (c) $\mathrm{NO}_{3}-\mathrm{N}$ are shown. Error bars represent the standard error of the mean. $(N=15)$.

the large cores $(P<0.001)$, and the surface soil $\mathrm{pH}$ increased with increasing soil $\mathrm{pH}$ (Fig. 7). In the small soil cores, the water treatment significantly affected soil $\mathrm{pH}(P<0.05)$ on Days 36 and 51 when the soil surface $\mathrm{pH}$ was higher in the saturated treatment $(\mathrm{pH} 5.5)$ than in the field capacity treatment ( $\mathrm{pH} 4.9)$. In the small cores, the soil $\mathrm{pH}$ only varied with depth on Days 8 and 19. Soil $\mathrm{pH}$ values, averaged across all soil $\mathrm{pH}$ treatments, at these times were highest on the surface of the 0 - to $2.5-\mathrm{cm}$ depth, $\mathrm{pH} 7.6$ and 6.0 on Days 8 and 19, respectively. The respective mean soil $\mathrm{pH}$ values did not differ between the 2.5 - to $5.0-$ and $5.0-$ to $7.5-\mathrm{cm}$ depths and averaged $\mathrm{pH} 5.8$ and 4.4 on Days 8 and 19, respectively. After $85 \mathrm{~d}$, the soil surface $\mathrm{pH}$ values in the large soil cores were well correlated to the initial soil $\mathrm{pH}$ values at the start of the experiment $(r=0.96)$, but were lower. For the six soil $\mathrm{pH}$ treatments listed above the respective values were 4.1, 4.3, 4.7, 5.7, 6.0, and 6.8. A regression of the final soil surface $\mathrm{pH}$ vs. the soil $\mathrm{pH}$ treatments fitted a quadratic relationship $(y=$ $\left.0.4 x^{2}-3.8 x+13.1 ; r^{2}=0.96\right)$ and showed that the higher soil $\mathrm{pH}$ treatments were closer to their original soil $\mathrm{pH}$.

The WSC levels in the large soil cores at destruction
Table 3. Rates of change in soil $\mathrm{NH}_{4}-\mathrm{N}$ and $\mathrm{NO}_{3}-\mathrm{N}$ concentrations (micrograms per gram dry soil per day) measured in the small soil cores as affected by lime treatment. Values are averaged over both water treatments. Negative values indicate decreasing concentrations in the soil.

\begin{tabular}{|c|c|c|c|c|c|}
\hline & \multicolumn{5}{|c|}{ Time, d } \\
\hline \multicolumn{6}{|c|}{$\mathbf{N H}_{4}-\mathbf{N}$} \\
\hline $\begin{array}{c}\text { Soil pH } \\
4.7 \\
5.3 \\
5.9 \\
6.6 \\
7.2\end{array}$ & $\begin{array}{l}0-8 \\
74 \\
67 \\
66 \\
57 \\
42\end{array}$ & $\begin{array}{r}8-19 \\
28 \\
15 \\
-5 \\
-9 \\
-23\end{array}$ & $\begin{array}{l}19-36 \\
-34 \\
-29 \\
-20 \\
-16 \\
-2\end{array}$ & $\begin{array}{r}36-51 \\
-3 \\
-2 \\
-1 \\
1 \\
1\end{array}$ & $\begin{array}{l}\mathbf{5 1 - 7 8} \\
-7 \\
-5 \\
-3 \\
-3 \\
-2\end{array}$ \\
\hline $\begin{array}{l}\text { LSD (0.01) } \\
\text { df }=25, n=6\end{array}$ & $\begin{array}{l}* * \\
16\end{array}$ & $\begin{array}{c}* * \\
\mathbf{3 5} \\
\text { NO } \\
\end{array}$ & $\begin{array}{c}* * \\
\mathbf{2 4}\end{array}$ & $\begin{array}{c}\text { NS } \\
11\end{array}$ & $\begin{array}{r}\text { NS } \\
6\end{array}$ \\
\hline $\begin{array}{l}4.7 \\
5.3 \\
5.9 \\
6.6 \\
7.2\end{array}$ & $\begin{array}{r}6 \\
8 \\
11 \\
13 \\
21\end{array}$ & $\begin{array}{l}35 \\
\mathbf{5 1} \\
\mathbf{6 2} \\
\mathbf{7 4} \\
\mathbf{8 1}\end{array}$ & $\begin{array}{r}-1 \\
-\mathbf{3} \\
-\mathbf{1 1} \\
-19 \\
-\mathbf{3 3}\end{array}$ & $\begin{array}{r}-9 \\
-26 \\
-32 \\
-33 \\
-29\end{array}$ & $\begin{array}{l}-7 \\
-5 \\
-3 \\
-3 \\
-2\end{array}$ \\
\hline $\begin{array}{l}\text { LSD }(0.01) \\
\text { df }=25, n=6\end{array}$ & $\begin{array}{r}* * \\
6\end{array}$ & * & $\begin{array}{c}* * \\
\mathbf{2 0}\end{array}$ & $\underset{45}{\mathrm{NS}}$ & $\begin{array}{r}\text { NS } \\
6\end{array}$ \\
\hline
\end{tabular}

$* \boldsymbol{P}<0.05$.

** $\boldsymbol{P}<\mathbf{0 . 0 1}$

$\dagger$ The least significant difference (LSD) between treatment means is shown for a $1 \%$ level of significance, $P$ values $>0.05=$ nonsignificant (NS).

were higher in the saturated soil (Table 4) with no significant soil $\mathrm{pH}$ treatment or depth effect. Total WSC was dominated by organic WSC with inorganic $\mathrm{C}$ contributing $<3 \%$ of the WSC at Day 85 . Water-soluble $\mathrm{C}$ was poorly correlated $(r=-0.44)$ with $\mathrm{N}_{2} \mathrm{O}$ fluxes at any depth on Day 85 during large soil core destruction. No relationship existed between WSC and the ratio of $\mathrm{N}_{2} \mathrm{O}$ $\mathrm{N} /\left(\mathrm{N}_{2} \mathrm{O}-\mathrm{N}+\mathrm{N}_{2}-\mathrm{N}\right)$ or the cumulative emissions of $\mathrm{N}_{2} \mathrm{O}$ and $\mathrm{N}_{2}$.

\section{DISCUSSION}

The magnitude, duration, and ${ }^{15} \mathrm{~N}$ enrichment of the $\mathrm{N}_{2} \mathrm{O}$ fluxes were affected by soil $\mathrm{pH}$ and soil water treatments. Similarly, the rate of nitrification and rela-

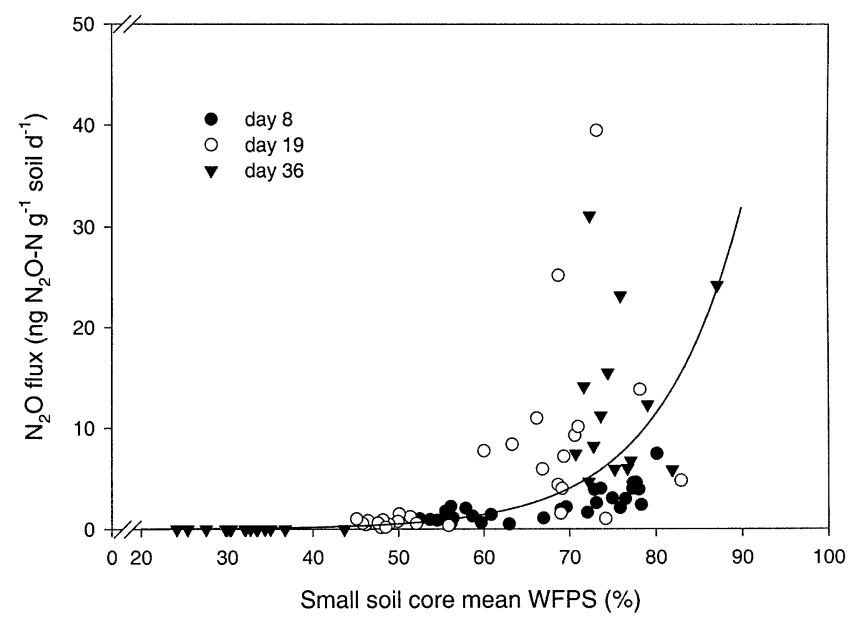

Fig. 6. Effect of water-filled pore space (WFPS) on the $\mathrm{N}_{2} \mathrm{O}-\mathrm{N}$ flux at three times following urine application, during small soil core destructive analysis. Water-filled pore space is the average of the entire soil core. Data points represent individual replicates. Fitted line is an exponential regression $\left[y=0.003 \exp (0.103 x), r^{2}=0.8\right]$ for all data points. 


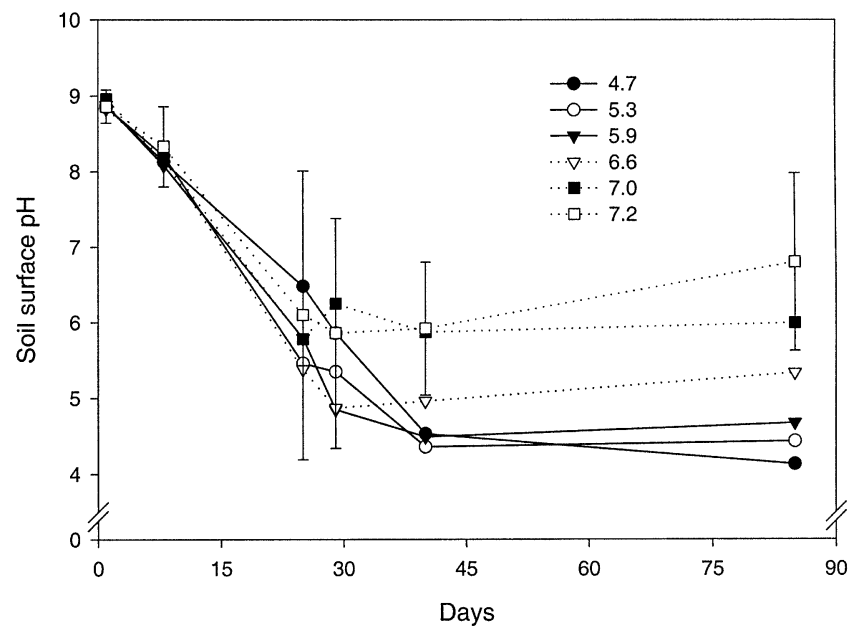

Fig. 7. Changes in initial soil surface pH over time following urine application. Data are average over both water treatments. Error bars represent the least significant difference between means at $1 \%$ level, $N=6$.

tive sizes of the soil inorganic $\mathrm{N}$ pools varied with soil $\mathrm{pH}$ and water treatment over time. The levels of soil inorganic $\mathrm{N}$ were typical of those found under urine patches (Williams and Haynes, 1994) but were at the high end due to the lack of potential for plant uptake and leaching. Without knowing the atom $\%$ of ${ }^{15} \mathrm{~N}$ abundance of the soil $\mathrm{NH}_{4}-\mathrm{N}$ and $\mathrm{NO}_{3}-\mathrm{N}$ pools over time, it is not possible to be definitive about the mechanism responsible for producing the $\mathrm{N}_{2} \mathrm{O}$. There was evidence of $\mathrm{N}_{2} \mathrm{O}$ reduction in the saturated soils where the $\mathrm{N}_{2} \mathrm{O}$ fluxes were lower in the 0 - to $2.5-\mathrm{cm}$ depth than from the remaining 2.5 to $7.5 \mathrm{~cm}$ of soil. This along with the lower soil $\mathrm{NO}_{3}-\mathrm{N}$ levels suggests that denitrification of $\mathrm{NO}_{3}-\mathrm{N}$ was responsible for a predominance of the $\mathrm{N}_{2} \mathrm{O}$ emitted from the saturated soil treatments. A further factor supporting the case for denitrifiers being active in the saturated soils are the relatively high $\mathrm{N}_{2}$ fluxes evolved.

Under both soil water treatments the atom \% of ${ }^{15} \mathrm{~N}$ enrichments of the $\mathrm{N}_{2} \mathrm{O}$ were less than the ${ }^{15} \mathrm{~N}$ enrichment applied indicating that other sources of $\mathrm{N}$, at natural abundance, contributed to the $\mathrm{N}_{2} \mathrm{O}$ fluxes. This natural abundance $\mathrm{N}$ potentially consisted of the glycine added in the urine, and soil inorganic $\mathrm{N}$ released as a result of soil mineralization of organic matter or deamination of soil organic matter under the high soil $\mathrm{pH}$ conditions occurring at the time of urea hydrolysis (Sen and Chalk, 1993). The assumption was made that the
$\mathrm{NO}_{3}-\mathrm{N}$ pool derived from the urine pool would be isotopically uniform. However, if as mentioned above, other native forms of inorganic $\mathrm{N}$ became available and were nitrified to form an unlabeled $\mathrm{NO}_{3}-\mathrm{N}$ pool then this assumption would be invalid if mixing of the $\mathrm{NO}_{3}^{-}$pools was incomplete. Thus ${ }^{15} X_{\mathrm{N}}$ would be too high and the calculated evolved $\mathrm{N}_{2}$ flux too low (Boast et al., 1988). The value of ${ }^{15} X_{\mathrm{N}}$ did not exceed the level of ${ }^{15} \mathrm{~N}$ enrichment applied.

The relatively large $\mathrm{N}_{2} \mathrm{O}$ fluxes that occurred under conditions of high WFPS $(>60 \%)$ are consistent with previous work that shows a dramatic increase in $\mathrm{N}_{2} \mathrm{O}$ emissions as WFPS exceeds approximately 60\% (Dobbie and Smith, 2001; Dobbie et al., 1999; Linn and Doran, 1984). The best relationship between $\mathrm{N}_{2} \mathrm{O}$ flux and WFPS in the small soil cores was provided by an exponential function (Fig. 6) although several data points at the highest $\mathrm{N}_{2} \mathrm{O}$ fluxes do not fit the relationship. If the four data points, to the left of the plotted relationship, with $\mathrm{N}_{2} \mathrm{O}$ flux $>20 \mathrm{ng} \mathrm{N}_{2} \mathrm{O}-\mathrm{N} \mathrm{g} \mathrm{g}^{-1}$ dry soil $\mathrm{d}^{-1}$ are removed the $r^{2}$ value increases only slightly to $r^{2}=0.83$. In fact the coefficients fitted, in this work, are very similar to those in the function of Fig. 8 from Dobbie et al. (1999). Small differences between the coefficients could be expected due to the varying experimental conditions. In general, the occurrence of high $\mathrm{N}_{2} \mathrm{O}$ fluxes in the presence of $\mathrm{NO}_{3}-\mathrm{N}$ substrate and high WFPS conditions support the view that high rates of $\mathrm{N}_{2} \mathrm{O}$ production are usually associated with denitrification as opposed to nitrification (Firestone and Davidson, 1989).

The higher flux ratio of $\mathrm{N}_{2} \mathrm{O}-\mathrm{N} /\left(\mathrm{N}_{2} \mathrm{O}-\mathrm{N}+\mathrm{N}_{2}-\mathrm{N}\right)$ in the field capacity treatment was possibly due to the presence of more aerobic conditions under the field capacity treatment. Thus any denitrified $\mathrm{N}_{2} \mathrm{O}$ may not have been reduced due to the effect of $\mathrm{O}_{2}$ on the $\mathrm{N}_{2} \mathrm{O}$ $\mathrm{N} /\left(\mathrm{N}_{2} \mathrm{O}-\mathrm{N}+\mathrm{N}_{2}-\mathrm{N}\right)$ ratio (Firestone et al., 1979). The higher flux ratio of $\mathrm{N}_{2} \mathrm{O}-\mathrm{N} /\left(\mathrm{N}_{2} \mathrm{O}-\mathrm{N}+\mathrm{N}_{2}-\mathrm{N}\right)$ in the saturated treatment on Days 12 and 26 may have been due to the presence of high soil $\mathrm{NO}_{3}-\mathrm{N}$ concentrations (Blackmer and Bremner, 1978; Koskinen and Keeney, 1982), however, this does not explain why the ratio was lower on Day 40 and 64 when soil $\mathrm{NO}_{3}-\mathrm{N}$ concentrations were elevated. Therefore, it is possible that $\mathrm{NO}_{2}-\mathrm{N}$ was having a greater effect on $\mathrm{N}_{2} \mathrm{O}$ reduction than $\mathrm{NO}_{3}-\mathrm{N}$. Soil $\mathrm{NO}_{2}-\mathrm{N}$ concentrations were elevated early in the experiment (Day 8) when nitrification and higher soil $\mathrm{pH}$ conditions existed and were also slightly elevated

Table 4. Water-soluble carbon (WSC) in large soil cores on Day 85 at three soil depths and under two soil water treatments (FC = field capacity, SAT $=$ saturated).

\begin{tabular}{|c|c|c|c|c|c|c|c|c|c|}
\hline \multirow[t]{3}{*}{ Soil depth } & \multicolumn{3}{|c|}{ Total } & \multicolumn{3}{|c|}{ Inorganic } & \multicolumn{3}{|c|}{ Organic } \\
\hline & & & & & ${ }^{1}$ dry $s$ & 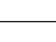 & & & \\
\hline & SAT & FC & & SAT & FC & & SAT & FC & \\
\hline $0-2.5$ & $1016(370) \dagger$ & $508(100)$ & *** & $4(4)$ & $2(2)$ & NS & $1012(367)$ & $506(100)$ & $* *$ \\
\hline $2.5-5.0$ & $660(84)$ & $387(50)$ & $* *$ & 16(6) & $5(2)$ & $* *$ & 644(81) & 382(48) & $* *$ \\
\hline $5.0-7.5$ & $643(97)$ & 417(75) & $* *$ & $5(5)$ & 1(1) & $* *$ & 638(98) & $416(75)$ & $* *$ \\
\hline
\end{tabular}

$* P<0.05$.

$* * \boldsymbol{P}<0.01$.

$\dagger$ Numbers in parentheses are the standard error of the means, $(N=3)$. $P$ values $>0.05$ are indicated as nonsignificant $(\mathrm{NS})$. 
on Day 26, during the peak denitrification period. Firestone et al. (1979) found that more $\mathrm{N}_{2}$ gas evolved, than $\mathrm{N}_{2} \mathrm{O}$, at very low $\mathrm{NO}_{2}-\mathrm{N}$ concentrations $(\leq 0.5 \mathrm{ppm})$, but when soil $\mathrm{NO}_{2}-\mathrm{N}$ concentrations were increased $(\geq 2 \mathrm{ppm})$ the percentage of $\mathrm{N}_{2} \mathrm{O}$ became dominant. The reason given for this was not because of more substrate being available for $\mathrm{N}_{2} \mathrm{O}$ production, because the total rate of $\mathrm{N}_{2} \mathrm{O}+\mathrm{N}_{2}$ production did not change, but the possible inhibition of the $\mathrm{N}_{2} \mathrm{O}$ reductase enzyme by $\mathrm{NO}_{2}-\mathrm{N}$.

Usually one might expect the $\mathrm{N}_{2} \mathrm{O}-\mathrm{N} /\left(\mathrm{N}_{2} \mathrm{O}-\mathrm{N}+\mathrm{N}_{2}-\mathrm{N}\right)$ ratio to decrease as soil $\mathrm{pH}$ increases (Simek and Cooper, 2002). The effect of soil $\mathrm{pH}$ on denitrification gas emissions and gas ratios is not as clear as in other studies that have examined the soil $\mathrm{pH}$ effect following $\mathrm{NO}_{3}-\mathrm{N}$ additions to soil (e.g., Waring and Gilliam, 1983). This is possibly due to the fact our experiment used urea-N as the major $\mathrm{N}$ substrate. When the urea hydrolyzed, the soil affected by the urine application had an average $\mathrm{pH}$ of 8.8 on the soil surface. It might be expected that this would effectively override any potential effect the original soil $\mathrm{pH}$ treatments might have had in the early stages of the urine- $\mathrm{N}$ transformations and $\mathrm{N}$ gas losses. However, previous work (Clough et al., 2003) and this study both show that soils of varying $\mathrm{pH}$, at field capacity, will evolve differing amounts of $\mathrm{N}_{2} \mathrm{O}$ following urine additions. This therefore suggests that the zone of $\mathrm{N}_{2} \mathrm{O}$ gas production is outside the zone of the high soil $\mathrm{pH}$ immediately affected by urea hydrolysis. This is possibly a result of inorganic $\mathrm{N}$ diffusion into the soil unaffected by urea hydrolysis and its associated soil $\mathrm{pH}$ changes. Thus any $\mathrm{N}_{2} \mathrm{O}$ production, via nitrifiers or denitrifiers, probably occurred at a site of original soil $\mathrm{pH}$.

By Day 19 any $\mathrm{NH}_{3}$ volatilization would have finished, with nitrification continuing, both processes that lead to decreases in soil pH (Bremner and Blackmer, 1981; Haynes and Sherlock, 1986). Hence, the observed decreases in the mean soil $\mathrm{pH}$ at depths 2.5 to 5.0 and 5.0 to $7.5 \mathrm{~cm}$ on Day 19 in small soil cores. This decrease in soil $\mathrm{pH}$ also provides another possible reason for the $\mathrm{N}_{2} \mathrm{O}-\mathrm{N} /\left(\mathrm{N}_{2} \mathrm{O}-\mathrm{N}+\mathrm{N}_{2}-\mathrm{N}\right)$ ratio to favor $\mathrm{N}_{2} \mathrm{O}$ soon after urine addition, that is, Day 12. Once $\mathrm{NO}_{3}-\mathrm{N}$ or $\mathrm{NO}_{2}-\mathrm{N}$ substrate was available denitrification could have occurred, particularly in the saturated soil. During denitrification $\mathrm{H}^{+}$ions are utilized (Cho et al., 1997). Thus the lower rates of soil $\mathrm{pH}$ decline in the saturated soils at high $\mathrm{pH}$, where denitrification rates might be expected to be higher (Simek and Cooper, 2002), may have been due to denitrification processes.

Biological denitrification can be limited by a lack of C (Firestone, 1982). Water-soluble C, extracted from air-dried soils, has been shown to be well correlated to denitrification potentials (Burford and Bremner, 1975). In the saturated treatment, concentrations of WSC were higher than those found by Burford and Bremner (1975), but in the field capacity treatment they were comparable with the highest concentrations of Burford and Bremner (1975). Solubilization of soil organic matter, resulting from the high soil $\mathrm{pH}$ conditions during urea hydrolysis, and the saturated soil conditions may have contributed to the high WSC levels measured. Interestingly, even though the relationship was poor, the $\mathrm{N}_{2} \mathrm{O}$ fluxes were negatively correlated $(r=-0.44)$ to the WSC during destruction of the large soil cores. Thus WSC was having some effect, either directly or indirectly, on reducing $\mathrm{N}_{2} \mathrm{O}$ fluxes. Water-soluble $\mathrm{C}$ was possibly available to denitrifiers for further reduction of the $\mathrm{N}_{2} \mathrm{O}$ to $\mathrm{N}_{2}$.

Nitrogen-15 label was used primarily as a tracer for $\mathrm{N}$ gas emissions from the urine and the aim was not to establish a full $\mathrm{N}$ budget. Nitrogen pools not measured included $\mathrm{NH}_{3}$ gas volatilization and inorganic $\mathrm{N}$ that diffused into the tension tables. These components could have accounted for the ${ }^{15} \mathrm{~N}$ not recovered.

Soil cores were placed for the duration of the experiment on water tension tables to try and maintain consistent values of WFPS. Other methods such as placing soil in glass jars or containers leads to soil being wetter at the bottom and drier at the surface. The tension table method was used to try and minimize this undesirable effect. A potential criticism of the tension table method used here is that under the conditions of the field capacity treatment, the porous silica flour may lead to greater downward movement of $\mathrm{N}$ gases than in the saturated treatment. This may in fact occur, but if it does it more closely resembles the real situation than if the soils had been maintained in glass jar microcosms, since gas can also diffuse downwards into the soil.

This study supports previous work showing that soil liming enhances nitrification (Haynes and Sherlock, 1986) and that cumulative $\mathrm{N}_{2} \mathrm{O}$ emissions under field capacity conditions are reduced with liming (Clough et al., 2003). This study, however, has also shown that under saturated soil conditions the cumulative fluxes of $\mathrm{N}_{2} \mathrm{O}$ and $\mathrm{N}_{2}$ are much greater than under field capacity conditions and are enhanced following liming. Naturally, any gains that may be made in reducing soil $\mathrm{N}_{2} \mathrm{O}$ emissions by liming also need be considered in the context of other possible increased emissions arising as the result of soil liming. These may include increased $\mathrm{CO}_{2}$ emissions as lime hydrolysis and/or increased $\mathrm{CO}_{2}$ resulting from elevated soil respiration.

Future experiments need to focus on defining the $\mathrm{N}_{2} \mathrm{O}$ production mechanisms. Nitrification inhibitors applied at discrete time intervals following urine application may provide a useful tool for this purpose. Nitrous oxide emissions from urine have been shown to be reduced when nitrification inhibitors are used (Di and Cameron, 2002). Alternatively discrete applications of ${ }^{15} \mathrm{~N}$ labeled inorganic $\mathrm{N}$ compounds to urine, previously applied to soil, at a series of time intervals may help elucidate $\mathrm{N}_{2} \mathrm{O}$ production mechanisms although problems with nonuniform labeling of $\mathrm{NO}_{3}-\mathrm{N}$ pools may arise.

\section{CONCLUSIONS}

Fluxes of ${ }^{15} \mathrm{~N}$-labeled $\mathrm{N}_{2} \mathrm{O}$ and $\mathrm{N}_{2}$ were measured from repacked soil cores limed to varying soil $\mathrm{pH}$ levels $(\mathrm{pH}$ 4.7-7.2), maintained at two water contents (field capacity and saturated), after treatment with a synthetic bo- 
vine urine treatment at $500 \mathrm{~kg} \mathrm{~N}^{-1}$. At field capacity the urine-induced $\mathrm{N}_{2} \mathrm{O}$ fluxes were lower and influenced by soil $\mathrm{pH}$, with total $\mathrm{N}_{2} \mathrm{O}-\mathrm{N}$ losses lowered at a soil $\mathrm{pH}$ of $\geq 5.9$ as well as a relatively large soil $\mathrm{NO}_{3}-\mathrm{N}$ pool remaining after 85 d. Under saturated conditions, $\mathrm{N}_{2} \mathrm{O}$ fluxes were up to four times higher than in the field capacity treatment, with lower $\mathrm{N}_{2} \mathrm{O}$ fluxes in the unlimed soil. The residual soil $\mathrm{NO}_{3}-\mathrm{N}$ pool was lower under the saturated treatments. Cumulative $\mathrm{N}_{2}$ fluxes were negligible in the field capacity treatment but were two orders of magnitude higher in the saturated treatment. Ratios of $\mathrm{N}_{2} \mathrm{O}-\mathrm{N} /\left(\mathrm{N}_{2} \mathrm{O}-\mathrm{N}+\mathrm{N}_{2}-\mathrm{N}\right)$ were highest under the field capacity treatment. This study suggests that while the use of soil liming, as an $\mathrm{N}_{2} \mathrm{O}$ mitigation option, for lowering soil $\mathrm{N}_{2} \mathrm{O}$ emissions from urine patches, has merit where soils are at field capacity, the resulting $\mathrm{NO}_{3}-\mathrm{N}$ pools will be susceptible to enhanced rates of $\mathrm{N}_{2} \mathrm{O}$ and $\mathrm{N}_{2}$ loss if soils are wetted up beyond field capacity.

\section{REFERENCES}

Arah, J.R.M., and K.A. Smith. 1990. Factors affecting the fraction of the gaseous products of soil denitrification evolved to the atmosphere as nitrous oxide. p. 475-480. In A.F. Bouwman (ed.) Soils and the greenhouse effect. John Wiley \& Sons Ltd., Chichester.

Bathurst, N.O. 1952. The amino acids of sheep and cow urine. J. Agric. Sci. 42:476-478.

Blackmer, J.M., and J.M. Bremner. 1978. Inhibitory effect of nitrate on reduction of $\mathrm{N}_{2} \mathrm{O}$ to $\mathrm{N}_{2}$ by soil microorganisms. Soil Biol. Biochem. 10:187-191.

Blakemore, L.C., P.L. Searle, and B.K. Daly. 1987. Methods for chemical analysis of soils. Manaaki-Whenua Press, Lincoln, New Zealand.

Boast, C.W., R.L. Mulvaney, and P. Baveye. 1988. Evaluation of nitrogen-15 tracer techniques for direct measurement of denitrification in soil. I. Theory. Soil Sci. Soc. Am. J. 52:1317-1322.

Bremner, J.M., and J.M. Blackmer. 1981. Terrestrial nitrification as a source of nitrous oxide. p. 151-170. In C.C. Delwiche (ed.) Denitrification, nitrification and atmospheric nitrous oxide. John Wiley \& Sons, New York.

Burford, J.R., and J.M. Bremner. 1975. Relationships between the denitrification capacities of soils and total, water soluble and readily decomposable soil organic matter. Soil Biol. Biochem. 7:389-394.

Cho, C.M., D.L. Burton, and C. Chang. 1997. Kinetic formulation of oxygen consumption and denitrification processes in soil. Can. J. Soil Sci. 77:253-260.

Clough, T.J., R.R. Sherlock, and F.M. Kelliher. 2003. Can liming mitigate $\mathrm{N}_{2} \mathrm{O}$ fluxes from a urine-amended soil? Aust. J. Soil Res. 41:439-457.

Crutzen, P.J. 1981. Atmospheric chemical processes of the oxides of nitrogen, including nitrous oxide. p. 17-44. In C.C. Delwiche (ed.) Denitrification, nitrification and atmospheric nitrous oxide. Wiley, New York.

Dendooven, L., L. Duchateau, and J.M. Anderson. 1996. Denitrification as affected by the previous water-regime of the soil. Soil Biol. Biochem. 28:239-245.

Di, H.J., and K.C. Cameron. 2002. The use of a nitrification inhibitor, dicyandiamide (DCD), to decrease nitrate leaching and nitrous oxide emissions in a simulated grazed and irrigated grassland. Soil Use Manage. 18:395-403.

Doak, B.W. 1952. Some chemical changes in the nitrogenous constituents of urine when voided on pasture. J. Agric. Sci. 42:162-171.

Dobbie, K., and K.A. Smith. 2001. The effects of temperature, waterfilled pore space and land use on $\mathrm{N}_{2} \mathrm{O}$ emissions from an imperfectly drained gleysol. Eur. J. Soil Sci. 53:667-673.

Dobbie, K., I.P. McTaggart, and K.A. Smith. 1999. Nitrous oxide emissions from intensive agriculture systems: Variations between crops and seasons, key driving variables and mean emission factors. J. Geophys. Res. Atmos. 104:26891-26899.

Duxbury, J.M., L.A. Harper, and A.R. Mosier. 1993. Contributions of agroecosystems to global climate change. p. 1-18. In L.A. Harper et al. (ed.) Agricultural ecosystem effects on trace gases and global climate change. ASA Spec. Pub. No. 55. ASA, Madison, WI.

Firestone, M.K. 1982. Biological denitrification. p. 289-326. In F.J. Stevenson (ed.) Nitrogen in agricultural soils. Agron. Monogr. No. 22. ASA and SSSA, Madison, WI.

Firestone, M.K., and E.A. Davidson. 1989. Microbiological basis of $\mathrm{NO}$ and $\mathrm{N}_{2} \mathrm{O}$ production and consumption in soil. p. 7-21. In M.O. Andreae and D.S. Schimel (ed.) Exchange of trace gases between terrestrial ecosystems and the atmosphere. John Wiley \& Sons, New York.

Firestone, M.K., M.S. Smith, R.B. Firestone, and J.M. Tiedje. 1979. The influence of nitrate, nitrite, and oxygen on the consumption of the gaseous products of denitrification in soil. Soil Sci. Soc. Am. J. 43:1140-1144

Fraser, P.M., K.C. Cameron, and R.R. Sherlock. 1994. Lysimeter studies of the fate of nitrogen in animal urine returns to irrigated pasture. Eur. J. Soil Sci. 4:439-447.

Haynes, R.J., and R.R. Sherlock. 1986. Gaseous losses of nitrogen. p. 242-302. In R.J. Haynes (ed.) Nitrogen in plant-soil sytems. Academic Press, New York.

Haynes, R.J., and P.H. Williams. 1993. Nutrient cycling and soil fertility in the grazed pasture ecosystem. Adv. Agron. 49:119-199.

Holtan-Hartwig, L., P. Dorsch, and L. Bakken. 2002. Low temperature control of soil denitrifying communities: Kinetics of $\mathrm{N}_{2} \mathrm{O}$ production and reduction. Soil Biol. Biochem. 34:1797-1806.

Koskinen, W.C., and D.R. Keeney. 1982. Effect of pH on the rate of gaseous products of denitrification in a silt loam soil. Soil Sci. Soc. Am. J. 46:1165-1167.

Laughlin, R.J., R.J. Stevens, and S. Zhuo. 1997. Determining nitrogen15 in ammonium by producing nitrous oxide. Soil Sci. Soc. Am. J. 61:462-465.

Linn, D.M., and J.W. Doran. 1984. Effect of water-filled pore space on carbon dioxide and nitrous oxide production in tilled and non tilled soils. Soil Sci. Soc. Am. J. 48:1267-1272.

Mulvaney, R.L. 1996. Nitrogen-Inorganic forms. p. 1123-1184. In D.L. Sparks (ed.) Methods of soil analysis. Part 3. SSSA and ASA, Madison, WI.

Mulvaney, R.L., and C.W. Boast. 1986. Equations for determination of nitrogen-15 labeled dinitrogen and nitrous oxide by mass spectrometry. Soil Sci. Soc. Am. J. 50:360-363.

Perez, T., S.E. Trumbore, S.C. Tyler, P.A. Matson, I. Ortiz-Monasterio, T. Rahn, and D.W.T. Griffith. 2001. Identifying the agricultural imprint on the global $\mathrm{N}_{2} \mathrm{O}$ budget using stable isotopes. J. Geophys. Res. Atmos. 106:9869-9878.

Rockmann, T., J. Kaiser, and C.A.M. Brenninkmeijer. 2003. The isotopic fingerprint of the pre-industrial and the anthropogenic $\mathrm{N}_{2} \mathrm{O}$ source. Atmos. Chem. Phys. 3:315-323.

Sarathchandra, S.U., and M.P. Upsdell. 1981. Nitrogen mineralisation and the activity and populations of microflora in a high producing yellow-brown loam under pasture. N. Z. J. Agric. Res. 24:171-176.

Sen, S., and P.M. Chalk. 1993. Chemical interactions between soil N and alkaline-hydrolysing N fertilizers. Fert. Res. 36:239-248.

Sherlock, R.R., S.G. Sommer, R.Z. Khan, C.W. Wood, E.A. Guertal, J.R. Freney, C.O. Dawson, K.C. Cameron, and G. Sven. 2002. Ammonia, methane, and nitrous oxide emission from pig slurry applied to a pasture in New Zealand. J. Environ. Qual. 31:14911501

Simek, M., and J.E. Cooper. 2002. The influence of soil pH on denitrification: Progress towards the understanding of this interaction over the last 50 years. Eur. J. Soil Sci. 53:345-354.

Stevens, R.J., and R.J. Laughlin. 1994. Determining nitrogen-15 in nitrite or nitrate by producing nitrous oxide. Soil Sci. Soc. Am. J. 58:1108-1116.

Stevens, R.J., R.J. Laughlin, and J.P. Malone. 1998. Soil pH affects the process reducing nitrate to nitrous oxide and di-nitrogen. Soil Biol. Biochem. 30:1119-1126.

Stevens, R.J., R.J. Laughlin, G.J. Atkins, and S.J. Prosser. 1993. Auto- 
mated determination of nitrogen-15-labeled dinitrogen and nitrous oxide by mass spectrometry. Soil Sci. Soc. Am. J. 57:981-988.

van der Weerden, T.J., R.R. Sherlock, P.H. Williams, and K.C. Cameron. 1999. Nitrous oxide emissions and methane oxidation by soil following cultivation of two different leguminous pastures. Biol. Fertil. Soils 30:52-60.

Waring, S.A., and J.W. Gilliam. 1983. The effect of acidity on nitrate reduction and denitrification in lower coastal plain soils. Soil Sci. Soc. Am. J. 47:246-251.
Whitehead, D.C. 1970. The role of nitrogen in grassland productivity Commonwealth Agricultural Bureau., Aberystwyth, Wales.

Williams, P.H., and R.J. Haynes. 1994. Comparison of initial wetting pattern, nutrient concentrations in soil solution and the fate of $15 \mathrm{~N}$-labelled urine in sheep and cattle urine patch areas of pasture soil. Plant Soil 162:49-59.

Wrage, N., G.L. Velthof, M.L. van Beusichem, and O. Oenema. 2001. Role of nitrifier denitrification in the production of nitrous oxide. Soil Biol. Biochem. 33:1723-1732. 